\title{
Impact of Scribing and Writing Mus'haf on Prosperity of Calligraphy in Iran
}

\author{
Hadi Arefi \\ Assistant Professor, Department of Graphic Design, Faculty of Architecture and Urban Design, \\ Shahid Rajaee Teacher Training University, Tehran, Iran
}

\section{Doi:10.5901/mjss.2016.v7n4s1p29}

\begin{abstract}
Calligraphy was born with the advent of Islam and in the name of the Word of God and with the grace of Ahl-e Bayt and was developed and achieved a higher level. One of the reasons for remarkable progress of calligraphy in Islamic countries, including Iran, is its association with the Qur'an and the sanctification of pen and writing, because recording religious texts and teachings demands accuracy and integrity. Letters and words in the Quran were inspiring for Muslims and caused the scriber to make innovations in writing styles to write the Quran which was appropriate and competent for the immortal book. This art was at last an outlet for emotional outbursts and representing the beauty of creation. So, an art was necessarily needed to emerge in Iran and other Islamic societies that was based on rationality, skill, knowledge and spirituality and in a word manifestation of the Islamic elements. Calligraphy among other Islamic arts has such functionality and aesthetic elements that was able to combine other arts such as pottery, brickwork, patchwork mirror work, wood carving, tiling, Girih tiles, painting and gilding and to be as a bride among Islamic arts. Due to the great love and passion to Quran and Ahl-e Bayt (AS), using Islamic elements arising from these two great valuable memento, Iranians could have a fundamental and substantial contributions in its dynamics and development.
\end{abstract}

Keywords: the Quran, writing, calligraphy, scribing and writing Mus'haf.

\section{Introduction}

Calligraphy is the most important art of Islamic civilization that has deep ties with the Islamic culture due to combination with writing Quran and religious, scientific and literary texts. Writing at the beginning served for recording and reproduction of religious, literary and scientific texts, therefore the only means of transfer and recording science and wisdom was scribing and of course, it had symptoms and signs which had the same letters. The signs clarifies how we should write and how we should contract to communicate between writer and reader. The text written by a scriber, should easily be understood by the reader. So, the task and commitment of transferring wisdom and knowledge is its primary component. Considering that the only means of recording and transmission of wisdom and knowledge was scribing, so it can be imagined how writing can be changed into art and an aura of holiness will be intertwined around them.

Calligraphy itself is not holy and its sanctity is raising from the word of God and due to transferring God's word. Part of the credit is because calligraphy is a vector of legal, literary, scientific, medical, historical, geographical and ... texts which is certainly a very major and worthwhile credit. However, it must be said that at the heart and core of this art, transferring noble, just and decent means becomes a constant commitment and duty and that is why we don't see in a text or calligraphy that a wrong, vulgar and obscene content is written with true style and good writing. This moral obligation was always observed in calligraphy and any written or piece of calligraphy brings the certainty and confidence that the reader will deal with a sacred text or reflecting an advice, wisdom and prudence. Due to the above, this research is an answer to the question whether in the rise and advance of calligraphy, a wisdom that should be transferred by it, is a determining factor or not? Or in other words, whether Islamic and spiritual values of texts are the main factors in originating calligraphy and its prosperity?

Therefore, there is a hypothesis for each question, in this study our hypothesis is based on the fact that a strong relationship exists between the Islamic and noble values and birth and development of calligraphy after the advent of Islam in the Muslim world, especially in Iran. So that the writers of the Quran, sayings and prayers have a more sublime and exalted position than other calligraphers. 


\section{The Formation and History of Calligraphy 1}

In Persian, this art was called calligraphy and one who write it beautifully with the rules of writing was called calligrapher (Dehkhoda, following " calligraphy " and "calligrapher", Sokhan grat dictionary, 2002, under "scriber"), but since around the tenth century, two terms of calligraphy and calligrapher became popular with the same meaning in the Persian (see, for example, Soltan Ali Mashhadi, 1993, p. 82; Doost Mohammad Heravi, 1993, p. 264). In Arabic, one of the meanings of calligraphy is writing with a pen (Zabidi, vol. 19, n.d, p. 248) and in detail, it is writing Arabic and its various practices and forms, but in the specific sense, the word calligraphy contains the concept of writing good and beautifully and calligrapher is one who has fine handwriting (Azarnoush, 2000, under the "calligraphy" and "calligrapher"). In this study, the purpose of handwriting and calligraphy is a calligraphy that conveys a message not only by its content but also attracts viewer attention by its beautiful appearance and encourages him to read. We can say that calligraphy for writing is the same as rhetoric for speech.

The importance of calligraphy is given from the position of writing and pen in Islam and the Quran, for example, the name of sixty-eighth surah is Qalam (pen). In the second verse of Tur Surah, it is swore to "written book", and verse 19 of Al-Haqah Sura and verse 11 of Enfetar Surah spoke about the deeds of men and of angels who are in charge of writing good and bad deeds.

Many traditions and sayings have been quoted from the great religious leaders and philosophers about the significance of calligraphy and writing, as almost all the articles written in the mid-Islamic era for education of calligraphy, have been begun with few traditions about calligraphy and sometimes independent parts of some papers have been dedicated to this news (for example, see: Abu Hayyan Tohidi, n.d, p. 248-268). In most Persian calligraphy papers which are often written after the eighth century, some words about the virtue of good writing were attributed to the Prophet (PBUH) and Imam Ali (AS). Some of these words are repeated in papers at different times and it is evident that quoting these words was widespread among the calligraphers, for example, a statement attributed to the Prophet saying that one who writes "Bismillah" with fine handwriting will enter the Heaven (Fethullah Sabzevari, 1993, p. 106). A narration is also narrated from Imam Ali (AS) that fine handwriting is the key of livelihood (Fethullah Sabzevari, 1994, p. 106). Quoting such words about the fine handwriting from the Imams (AS) was mostly common among Iranian calligraphers.

In some cases, some notes regarding reforming tools and materials and training calligraphy are attributed to the Prophet (for example, see: Samaani, 1989, p. 188). Some hadith books said that Ali (AS) said to Obaidullah ibn Abi Rafe the scriber that, "Put silk in inkholder and carve the pen long and let gap among the rows and write letters small and close together." (See: Nahjolbalagha, 1991, p. 418). Saying aphoristic statements about the virtues of calligraphy is not limited to verses and hadiths mentioning, but also the calligraphers attributed such sentences to many celebrities and sages, from Euclid and Galen, Plato to Umar ibn Khattab and Mamoon Abbasi (Abu Hayyan Tohidi, n.d., pp. 254-267).

Writing in the Islamic world began with the revelation scribers (Mayel Heravi, 2001, p. 78). The importance of calligraphy in scribing Quran caused calligraphers to quote many traditions and sayings about religious leaders. The importance of calligraphy in the Islamic world is mostly due to its link with the writing of Qur'an. There is controversies about the first calligraphy or calligraphies used in writing Qur'an. (Ibn al-Nadim, 1971, p. 9). The first Arabic calligraphies were Maki, Medinan, Basri and Kofi, respectively. Based on the location of the Quran revelation and the development of cultural centers in Iraq, the order of calligraphies used in writing the Mushafs were the same. The name of these four calligraphies along with twelve others is give in Al-Fihrist book. After the transfer of the caliphate to Kufa, calligraphies of writing Qur'an became very diverse that all were called Kofi.

Kufic script for scribing the Qur'an was spread in other Islam territories and found a new form in any specific area, such as East or West Kofi (Fazaeli, 1997, p. 142). East Kofi that was including various Arabic and Persian method were applied in writing Mus'haf until the end of the sixth century and then until the tenth century, was used in writing the chapters and buildings' inscriptions and manuscripts (Fazaeli, 1977, p. 149). In Iran, the first script used for writing the Qur'an was Piramouz script which quality is unknown (Ibn al-Nadim, 1971, p. 9)

\section{Calligraphy Art in the Field of Iranian History}

Muslim conquests and transferring Caliphate center from Iraq to Syria in the beginning of the Umayyad caliphate, lead to the publication of Arabic script to other lands. The flourishing of the arts of calligraphy and innovation and continuous reform of the scripts was continued in Umayyad period and then until the end of the third century. At this time, a variety of

\footnotetext{
${ }_{1}^{1}$ Parts of this article are derived from entries of "calligraphy 1 and 2" by Mehdi Sahragard and Valiollah Kavoosi. For more information
} about the formation and history of calligraphy in the Islamic communities refer to the entries listed in Islamic Encyclopedia. 
items was so that there was a particular script for any purpose. (Ibn al-Nadim, 1971, pp. 10-11). Ibn Nadim brought the names of some of these scripts and their use in Al-Fihrist, including Toomar font was used for writing letters to the leaders and rulers, Tholtehin for correspondence with subordinate rulers, Mofateh and Moamerat for litigation, Ashriyeh for releasing servants and real estate transaction, and round for writing poems and sayings. According to him, all the scripts are derived from four scripts like Jalil, Toomar Kabir, Nesf Saqil, and great Tholth and last items are extracted from the Jalil script that is the father of all items (Ibn al-Nadim, 1971, 11).

However, in the late third century, the number of calligraphers and diversity of calligraphy reached a point that reforming and classification of items and development of specific rules for calligraphy was essential. This was done in early fourth century by Ibn Moghleh (d. 328).

Ibn Moghleh who was minister in three powerful, omnipotent and satisfied Abbasid Caliphates, in collaboration with his brother, Abu-Abdullah Hussein bin Ali, imposed the calligraphy rules based on geometry principles. It is well known that from among the mass popular fonts in those days, Ibn Moghleh chose and regulated six fonts called Mohaqeq, Reyhan, Tholth, Naskh, Toqi and Roqae. These fonts later as the six fonts (Aqlam Sette) became known as the most important fonts of calligraphy. ${ }^{2}$

Noskh was used in the fourth century and found a particular local form with Iranian initiatives, which reading was easy compared to Kufic script, the invention and use of a variety of Islamic scripts continued and with the establishment of Islamic schools during the Seljuk period (429-590), with the support of people like Khaje Nezam al-Mulk, resulted in booming of writing the Qur'an, because a library was established in each of these schools. In Syria and Iraq, the establishment of these schools caused more popularity of writing Quran (James, 1922, vol. 2, p. 22-23). In the seventh century, the rise of Yaqout Mostasemi in Mostasem Billah system, the last Abbasid caliph, forwarded writing Qur'an another big step. His presence in court of Hulaku Mughal and his minister Atta Malek Juwayni in Baghdad had a profound effect on the next generation of the Iranian Quran writers (James, 1922, vol. 2, p. 58). Monshi Qomi writes in Zekr Yaqout: "When he became Qibla-Alkitab, he wrote two parts of Quran every day, and he finished two book every month ..." (Monshi Qomi, 1973, p. 25), and then in a report, he narrated that Yaqout at the time of the conquest of Baghdad in $656 \mathrm{AH}$ by Holakukhan, fled to a shop where he had inkwell and creates a miracle work on a piece of fabric. Monshi Qomi then tells that the same day, one of his students come to the master and notified him about the conquest of Baghdad and killing and looting Mongol, but in response, Yaqout said his student : "no sorry because I have written enough which worth more than the world, no fear if Baghdad falls ... "(Monshi Qomi, 1973, pp. 25-24)

Until the early seventh century $\mathrm{AH}$, Iranians who were once again attacked by Mongols used the Kufic script and six fonts. (Ghelichkhani, 2013, p. 32) After the attacks and because Mongols were non-Muslim, writing Quran was reduced somewhat, but when Ghazan Khan joint Islam in 695 and with his minister support, Khwaja Rashid al-Din Fadlallah, of art and calligraphy, writing Quran was again boomed (James, 1992, vol. 2, p. 23, 58). According to James, ten copies of the Yaqout Mus'haf were gathered by Khwaja Rashid al-Din in Robe Rahidi and the Mus'hafs were the model for many writers in eighth century.

At the same time with the fall of Mongol invasion to Iran and healing heart-rending pains, some secretaries and scribers who were writer in the court of rulers, gradually used new scripts which later was called Taliq rather than Roghae and Tawqi. The reason for the creation of this script in addition to the inner desire of Iranian writers and scribers, was secretaries' need to a different script in writing, the font that is not too readable and simple and also demonstrates expertise of secretaries. Presence of Taliq and its cursive in sixth and seventh centuries can be seen. The script was first Iranian script that is called "Tarassoli" and "Name" fonts. (Ghelichkhani, 2013, p. 85). It should be noted that the Taliq is mostly related to the field of correspondence and writing, and was more used in writing documents, facilities and provisions and for writing Quran and religious prayers and poets' Diwan and even for transcription of manuscripts, as before, it was done using Kofic and Naskh fonts. Of course there are exceptions that are noted below.

The growing trend of writing Mus'haf in the Timurid period (807-913) was also continued. According to Monshi Qomi, at the end of the Timurid empire, a calligrapher called Omar Aqta wrote a great book with Mohaqeq font for Timor. After Timur, his grandson Ibrahim Sultan, who himself scribed Qur'an and also supported Quran scribers, changed Shiraz into one of the main centers of Mus'haf writing. (Monshi Qomi, 1988, p. 25) In the ninth century, Turkmen of Aq-qoinlu were also supporters of book writing. In this era, a calligrapher called Zein Al Abedin Ben Mohammad Kateb Shirazi

\footnotetext{
2 The first Iranian calligraphy experiences were associated with the elimination of Pahlavi script and replacement of Kufic script and since the fourth century, it was known as a valuable, independent and genuine art with presence of geniuses like Ibn Moghleh Farsi and with transition from numerous development has come to us. For information on the state of the Iranian calligraphy during the early centuries of Islam and the Middle Ages and the subsequent development of this art to the contemporary period, see: Shahroudi, 2009, pp. 40-17; and Hamid Reza Ghelichkhani, 2013, pp. 200-37.
} 
scribed a Mus'haf in thirty pieces with Mohaqeq, Tholth and Naskh for Yaqoub Beyg Aq-qoinlu (James, 1992, vol. 1, p. 15), (Fazaeli, 1997, pp. 332-333).

Following the tumultuous history of Iran, Safavid era was excelled in terms of social conditions and enabling the production of fine arts in various fields including calligraphy and we saw the emergence of popular calligraphers in this course of the history of our country, and in the meantime, some of the country, including Fars, Isfahan and Azerbaijan introduced figures and even recorded schools in their name. Professor Mirza Ahmad Neirizi is one of the main figures of this course that using his talent and pen in writing the Koran, prayer, Sahife Sajadieh and other Islamic books, remained in the hearts of Muslims and art lovers around the world forever and by nurturing students directly or indirectly in the next generation gave stability to the continuation of the art. ${ }^{3}$

However, in the tenth century, Persian scripts especially Nastaliq were widely used in writing literary texts, these fonts were rarely used in writing the Quran. Even sometimes writing the Qur'an with Nastaliq was considered ominous (Monshi Qomi, 1988, p. 97). This is largely due to the visual characteristics of Nastaliq, especially difficulty in parsing. Thus, in Iran, since the Safavid period until the end of the Pahlavi period, less than ten books were written in Nasta'liq (Schimmel, 1989, p. 1719). Scripts used in writing the Koran in the Timurid period (Reyhan, Mohaqeq, Tholth and Naskh) lasted by the end of the tenth century. Then, Naskh was almost replaced for all the old ones. One of the main reasons for this was small and medium sized books that it was not possible to use underhand scripts, as Mohaqeq. Tradition of writing Quran was revived in the early twelfth century, at the period of Shah Soleiman and Shah Sultan Hossein Safavi. One of its result was writing the Persian translation as a narrow band with Nastaliq font under the verses and it's other result was the emergence of Ahmad Neirizi method in writing Naskh font that became famous as Iranian Naskh. The features of Neirizi Naskh were the relatively large size of letters and long spacing between lines. This method of writing Quran remained during Zand and Qajar periods and in the two periods, Naskh was the special font for writing Qur'an (see Bayani and Stanley, pp. 126-130).

The thirteenth century in Iran was the period of calligraphy boom and subsequently, book writing was also flourished supported by court and sometimes people orders and outstanding personalities. In this period, the common font in writing Quran was yet Iranian Naskh. Famous calligraphers such as Wesal Shirazi and his children, ${ }^{4}$ Ali Askar Arsanjani and his son Mohammad Shafi, ${ }^{5}$ Zein al-Abedin Esfahani (Ashraf al-Kotab) and his leading disciples and some women like Umm Salamah, the daughter of Fath Ali Shah and Maryam Banoo Naeini were active in writing the Naskh and Mus'haf-writing (Fazaeli, 1997, pp. 356-363). However, the nature of the script in the Qajar period shifted from writing book or Chalipa ${ }^{6}$ scripting towards writing Siah Mashq. (Ghasem Ahsant, 1998, p. 24) Here, however, with the decline of calligraphy in the course of content of the produced works is not techniques of calligraphy, people like Mirza Fatali Hejab Shirazi, the outstanding calligrapher of first half of the thirteenth century, with the acquisition and development of

\footnotetext{
${ }^{3}$ To know about the history, style and works of Mirza Ahmad Neirizi, see: (Proceedings of the Congress by Professor Mirza Ahmad Neirizi, vol. 1, collected by Ali Akbar Safipour and Mansoor Tabiei, Shiraz: Adib Mostafavi Publications, 2001).

${ }^{4}$ Mirza Ismail and Mirza Mahmoud children of Wesal Shirazi were also great and popular poets and calligraphers in thirteenth century. Their pseudonym were Tohid and Hakim, respectively. Tohid had a special ability in writing and wrote Naskh and Tholth better than his contemporaries. Many Qur'ans remained from him that some of them were written on deer skin with very tiny fonts and some others are written with several fonts. His skill in fine writing was so that he wrote Tawhid surah on a rice that the rice he wrote on them can still be found. He also wrote three Masnavi for Mostoqfi al-Mamalek, Hessam al-Saltaneh and Haji Motamedodoleh. His brother Hakim was very skilled in writing Naskh and Nastaliq, especially with a Khafi pen. In his first year of accommodation in India, he wrote Diwan Hafez with nasta'liq font. A collection of poems by Ishrat Wesal (d. 1939), the full course of Rozato-safa by Mīr-khuānd and a copy of Jami works are among his calligraphy works. For more information, see: (entries of "Tohid Shirazi" and "Hakim Shirazi" in the Islamic Encyclopaedia) ${ }^{5}$ For information on the Life, Style and Works of Arsanjani and his family, see: (Mahmoud Tavousi, "dynasty of Arsanjani in the field of calligraphy," Proceedings of scribing and calligraphy 1, Tehran: Cultural Heritage and Tourism Organization, 2006, pp. 135)

${ }^{6}$ Chalipa is one of the most versatile forms and styles of writing in calligraphy, especially in Iran. Chalipa is writing two verses or four hemistiches diagonally, with the same theme and message, in a rectangle page. So that they should proportion four lines of a poetry, that might be uneven and inconsistent in terms of letters and word geometry, while in total and in each row, common ratios as a chain have continuity and all principles of aesthetics are observed in it. Two meanings are inferred from the word Chalipa and its relation with calligraphy,: 1) examples of works where the seat of the words is "diagonal" and rows are set as familiar seats of calligraphy (horizontal seats), that its sample can be seen in the historical calligraphy works, mostly in the works before the ninth century and in six lines and the suspension scripts, 2) four diagonal seats that are set with certain ratio based on the assumed vertical and horizontal lines) and their rise can be seen in the history of calligraphy with greater clarity, after the invention of nasta'liq and then broken, after the ninth century. Due to the popularity of Chalipa in the second sense, what the ancients called Chalipa was known as skew writing. Chalipa built a strong relation with ancient Persian poetry, and it becomes as one of the most widely used and accepted methods of writing and calligraphy, especially Nastaliq and cursive. For more information about Chalipa, see (entry to "Chalipa" in the Islamic encyclopedia)
} 
Miremad Font, pave the way for flourishing calligraphy from the perspective of the art techniques ${ }^{7}$. One reason for this decline is probably due to the introduction of the printing industry in the late Qajar era. With the introduction of the printing industry in the second half of the nineteenth century, Qur'an writing tradition was abandoned and instead, the printed Qur'ans with Naskh font were common. (Schimmel, 1989, p. 17).

\section{Conclusion}

People in peninsula at the death of the Prophet (PBUH) in the eleventh year were still illiterate and their only script was a simple and without elegance script that few were aware of it. Centuries later, at the establishment of the Abbasid Caliphate in Baghdad, Arabic script was not only modified, but also calligraphy was gradually found its place in the Islamic world. For such a development, we can mention several reasons that before all of them is the nature of the holy Quran. Since the Quran was God's direct revelation, it should be first properly recorded and written, and thus it resulted in correction of script. Second, it must be written so that no one does hesitate in its noble origin. On the other hand, due to the lack of acceptance of arts such as iconography and sculpture arts in Islam, those interested in various arts, including new Muslim artists had to express their perception from the world by means of writing. In any case, scribing and book writing was considered the only means of recording and transmission of wisdom and its juxtaposition with religious texts and prayers led to have a sublime and exalted position in the Islamic Arts.

\section{References}

Quran

Nahjolbalagha, translator Jafar Shahidi, Tehran 1991.

Ibn Nadeem, Al-Fihrist Book, Reza Tajjadod Print, Tehran: 1971.

Abu Hayyan Tohidi, Abu Hayyan al-Tohidi epistles, Ebrahim Gilani printing, Damascus, n.d.

Ahmad bin Hussein Monshi Qomi, art garden, edited by Ahmad Soheili Khansari, Tehran: Iranian Cultural Foundation Press, 1973.

Ahmad bin Hussein Monshi Qomi, art garden, Ahmad Soheili Khansari printing, Tehran, n.d., 1987.

Azartash Azarnoush, contemporary Arabic-Persian Dictionary, Tehran: Bina, 2000.

Annemarie Schimmel, calligraphy and Islamic culture, translated by Asadullah Azad, Mashhad, Astan Qods Razavi Publications, 1989.

Habibollah Fazaeli, training calligraphy, Tehran: Soroush, 1997.

Hamid Reza Ghelichkhani, Introduction to Iranian calligraphy, Tehran: Contemporary Dictionary, 2013.

Darwish Mohammad Bin Dost Mohammad Bokhari, principles of calligraphy, Majib Mayel Heravi, book layout in Islamic civilization, Mashhad: Bina, 1993.

Dost Mohammad Heravi, History of Dost Mohammad Gavashan Heravi, Najib Mayel Heravi, book layout in Islamic civilization, Mashhad: Bina 1993.

Abdul-Karim Bin Mohammad Samaani, Adab al-imla' wal-istimla, Saeed Mohammed Loham printing, Beirut, 1989.

Ali Akbar Dehkhoda, Dehkhoda Dictionary, Tehran: Tehran University, Dehkhoda Dictionary Institute, 1982.

Fethullah bin Ahmad Sabzevari, rules and principles of six lines, Majib Mayel Heravi, book layout in Islamic civilization, Mashhad: Bina, 1993.

Sokhan great dictionary, led by Hassan Anvari, Tehran, Sokhan, 2002.

Forough, Ali Shahroudi, the development of calligraphy in Iran, Tehran: Resanesh Publication, 2009.

Ghasem Ahsant, Miremad to Hejab Shirazi, Shiraz: Ofogh Parvaz Publications, 2008.

Professor Mirza Ahmad Neyrizi Congress Proceedings, vol. 1, effort by Ali Akbar Safipour and Mansoor Tabiei, Shiraz: Adib Mostafavi Publications, 2011.

Mohamed Bin Mohammad Zabidi, Tajol-Arous men Javaherolqamous, Vol. 19, Abdul-Aleem Tahavi Print, Kuwait 1980, offset Beirut: n.d.

Najib Mayel Heravi, history of manuscript and critical correction of manuscripts, Tehran: 2001.

Najib Mayel Heravi, book layout in Islamic civilization, Mashhad: Bina, 1993.

David James, after Timur: Qur'ans of the $15^{\text {th }}$ and $16^{\text {th }}$ centuries, in ibid, vol. 2.3, 1992

Manijeh Bayani and Tim Stanley, "Iran: the late Safavid renewal and Ahmad Neyrizi", ibid.

${ }^{7}$ For more information about the life and art of calligraphy of Hejab Shirazi, see: (Ghasem Ahsant, Miremad to Hejab Shirazi, Shiraz: Ofogh Parvaz Publications, 2008, pp. 31-14). 